homology to the Drosophila engrailed gene. We recommend that this map serve as the basis for future nomenclature of the mouse genes and that this system of nomenclature be-used as a prototype for naming homoeobox-containing genes or genomic sequences from other vertebrate species. When there is strong evidence to suggest that a given gene is a homologue of a specific mouse Hox locus, it should assume the same designation. For example, the independently isolated $\mathrm{Hu}-1$ (ref. 9) and $\mathrm{c10}$ (ref. 17) sequences represent the same human gene, which is the homologue of the mouse Hox-2.1 locus, and this designation should be used in future publications describing that human gene.

GAIL R. MARTIN

Department of Anatomy,

School of Medicine,

University of California,

Sán Francisco,

California 94143 ,

USA

Co-Authors: Eduardo Boncinelli, Denis Duboule; Peter Gruss, Ian Jackson, Robb Krumlauf, Peter Lonai, William McGinnis, Frank Ruddle \& Debra Wolgemuth.

\footnotetext{
1. Grusș, P. \& Kessel, M. Nature 322, 780 (1986).

2. Mouse News Lett. 72, 2 (1985)

3. McGinnis, W., Hart, C.P., Gehring, W.J. \& Ruddle, F.H. Cell 38, 675-680 (1984)

4. Colberg-Poley, A.M., Voss, S.D., Chowdhury, K. \& Gruss, P. Nature 315, 713-718 (1984).

Colberg-Poley ${ }_{m}$ A.M. et al. Cell 43, 39-45 (1985)

6. Wolgemuth, D.J. $J_{\lambda}$ et al. EMBO J. 5, 1229-1235 (1986)

7. Duboule, D., Baron, A., Mahl, P \& Galliot, B. EMBO J. S, 1973-1980 (1986)

8. Rubin, M.R. et at. Science 233, 663-667 (1986).

9. Hauser, C.A. et al. Cell 43, 19-28 (1985)

10. Hart, C.P. et al. Cell 43,9-18 (1985)

1. Hart, C.P. el al. Cell 43,9-18(1985).

Jackson, I.J., Schofield, P. \& Hogan, B. Nature 317, 745 748 (1985)

12. Awgulewitsch, A. et al. Nature 320, 328-335 (1986)

13. Breier, G. et at. EMBO J. 5, 2209-2216 (1986).

14. Lonai, $P$. (unpublished data)

15. Joyner, A.L. et al. Cell 43, 29-37 (1986).

16. Joyner, A.L. \& Martin, G.R. Genes Dev, (in the press)

17. Simeone, A et al. Nature 320, 763-765 (1985)
}

SiR-As chairman of the Committee on Standardised Genetic Nomenclature for Mice I have agreed the rules proposed by Gail Martin et al. for naming mouse homoeobox genes and should like to endorse their suggestion that the rules are followed in other species. I should also like to suggest that the rules for naming genes in all mammalian species follow those for the mouse. The mouse and man are the two genetically best understood mammals. Which of the two is better understood is an arguable point. What is unquestionable is that genetic nomenclature for the mouse has been studied, developed and refined for far longer than that of man.

One recent point of concern is the tendency of some authors to suggest gene names beginning with a letter to denote the species in which they occur - for example $\mathbf{H u}-\mathbf{I}$ for a human homoeobox ${ }^{1}$ and Mox for mouse homoeoboxes ${ }^{2}$. If such a policy were taken seriously, all genes in man would begin with the letter $\mathrm{H}$ and all in mouse with the letter M. As there are already $1,000-2,000$ named loci in each species, and these numbers are expected to rise to $10^{4}-10^{5}$, this would be remarkably inconvenient and uninformative. It is also against the nomenclature rules of both species, which state that "terminology for homologous genes should be standardised among species"3,4. In all but a few cases, such as transgenic animals, the species of origin of a gene is obvious from the context.

A second point concerns the use of upper and lower case letters in gene symbols. Since gentetics began, it has been traditional to use both cases of letters, with the initial letter upper case for dominant and codominant genes, and with additional use of the two cases to denote phenotypes, members of gene complexes, genes which are members of a series, and so on. Recently, human gene nomenclature has departed from this in using upper case letters throughout. This is most undesirable as it means the loss of one means of conveying information. $\mathrm{A}$ problem my committee faces with increasing frequency is that the amount of known information is too great to be conveyed in the symbol. Therefore, let us keep all means of conveying this information, including upper and lower case letters, numbers, hyphens and superscripts.

MRC Radiobiology Unit,

Chilton, Didcot,

Oxon OX11 ORD, UK

1. Levine, M., Rubin, G.M. \& Tjian, R. Cell 38, 667-673 (1984).

2. Gruss, P. \& Kessel, M. Nature 322, 780 (1986)

3. Mouse News Lett 72, 3, 10 (1985)

4. Shows, T.B. et al. Cytogenet. Cell Genet. 25; 96-116 (1979)

\section{Micro megafaunal mounds}

SIR-How big is a megafauna? Smith, Jumars and De Master (Nature 323, 251; 1986) refer to "sediment mounds composed of faecal material from megafaunal deposit feeders". I was intrigued because of my interest in Pleistocene megafaunas. I then read that the organisms referred to are echiuran worms (Prometor benthophila), some $55 \mathrm{~mm}$ long. As 'megafauna' also refers to living or extinct large vertebrates, and 'microfauna' refers to vertebrates at the lower end of the vertebrate size scale, most of which are larger than echiuran worms, I wonder at the appropriateness of the terms.

The size of large cephalopods, ammonites and arthropods exceeds that of echiuran worms by a factor of ten or more, so the worms are not even in the upper size range of invertebrates. Perhaps "megainvertebrate' should describe the largest, 'macro-' or 'mesoinvertebrate' the midsize range, and 'microinvertebrate' the smallest metazoans.

At least, biologists should get the vertebrate megafaunal and microfaunal cate- gories to overlap those of the invertebrates, if the terms are to be used without any modifier; perhaps animals in the 500 $\mathrm{mm}$ to $2.5 \mathrm{~m}$ size range should constitute the mesofauna (or macrofauna).

C.S. CHurcher

Ramsay Wright Zoological Laboratories, University of Toronto,

Toronto, Ontario,

Canada M5S 1A1

\section{Plant leaves may not be excreting}

SIR-Ford has proposed a new function for plant leaves, that of 'excretophore', a tissue which serves as a means of disposal of metabolic waste products during leaf fall ${ }^{1}$. Three common secondary plant compounds are cited as examples of metabolic waste or excretory products. The history of secondary plant metabolism from Kossel onwards ${ }^{2}$ has been a progressive movement from unknown functions towards areas where a function is of suspected or, occasionally, proven significance in such fields as growth regulation (terpenoids), anti-herbivory (alkaloids and cyanogenic glycosides), phytoalexins (stilbenes) and allelopathic agents (phenolic acids) ${ }^{3}$. There is as yet no incontroversial proof that higher plants produce any waste products other than, arguably, $\mathrm{CO}_{2}, \mathrm{O}_{2}$ and $\mathrm{H}^{+}$ in respiration, photosynthesis and ionic adjustment. This is precisely what might be expected of the successful autotroph.

End products of secondary metabolism must not be written off as so much waste because of ignorance of their true function. Nor is it necessary to evoke complex tissues such as leaves in which to isolate metabolic 'unknowns'. Every mature cell in higher plants, unlike those of animal systems, is well endowed with vacuoles whose functions include the sequestration and long-term isolation of compounds which are otherwise inimicable to primary metabolic processes in the cytosol ${ }^{4}$. These vacuolar isolates may play a significant role in the defence of the cell against herbivores and fungal pathogens ${ }^{5}$. There is no sound evidence that such vacuolar compounds, which incidentally include Ford's anthocyanins (galloyl-) tannins and oxalates, are just bursting to be excreted in one gloriously colourful autumnal flush. Otherwise one is forced to ask of a mutant which fails to complete leaf senescence ${ }^{6}$, is it in any way constipated?

George Hendry

NERC Unit of Comparative Ecology,

University of Sheffield,

Sheffield S10 2TN, UK

1. Ford, B.J. Nature 323, 763 (1986).

. Ouoted in Czapek, F. Biochemie der Pflanzen 2 Aufl. 3 (Fischer, Jena, 1921)

3. Harbourne, J.B. in Encycloped. pl. Physiol. 8, 330-402 (Springer, Berlin, 1980)

4. Matille, Ph. New Phytol. 105, 1-45 (in the press).

. Hendry, G.A.F. New Phytol. 102, 239-247 (1986)

6. Hilditch, P., Thomas, H. \& Rogers, . Planta 167, 146-151 (1986). 